\title{
Top-down trophic shifts in Florida Keys patch reef marine protected areas
}

\author{
K. Lindsey Kramer ${ }^{1,2,3, *}$, Kenneth L. Heck Jr. ${ }^{1,2}$ \\ ${ }^{1}$ Dauphin Island Sea Lab, 101 Bienville Boulevard, Dauphin Island, Alabama 36528, USA \\ ${ }^{2}$ Department of Marine Sciences, University of South Alabama, Mobile, Alabama 36688, USA \\ ${ }^{3}$ Present address: National Park Service, Pacific Island Network, I \& M Program, PO Box 52, Hawaii National Park, \\ Hawaii 96718, USA
}

\begin{abstract}
Special Protected Areas (SPAs) were established within the Florida Keys National Marine Sanctuary in 1997 to address a variety of management goals including coral reef resource protection and recovery. Within these areas all consumptive activities are prohibited. To evaluate whether SPA establishment has resulted in reef assemblage differences on inshore patch reefs, we quantified reef fish abundance and biomass, grazing intensity and benthic cover on abiotically similar protected and reference reefs. Transect surveys indicated that biomass and mean body lengths for several common predatory fish species were significantly greater within SPAs. Size classes of herbivorous fish also varied with protection; adult herbivorous fish were significantly more abundant, while juveniles were significantly less abundant within SPAs. Grazing intensity and benthic cover were site-specific and did not vary consistently with protection, suggesting that SPA establishment has not immediately (within $10 \mathrm{yr}$ ) driven observable indirect effects on the benthos.
\end{abstract}

KEY WORDS: Marine reserve $\cdot$ Coral reef $\cdot$ Florida Keys $\cdot$ Trophic cascade $\cdot$ Parrotfish $\cdot$ Herbivory

\section{INTRODUCTION}

Scleractinian corals play a critical role in the reef community by creating protective habitat for all other reef residents. However, recent surveys of reefs in the Florida Keys, USA, document alarming declines in coral cover and species richness, and rapid shifts from coral to macroalgal dominance (Beaver et al. 2005). Numerous anthropogenic and natural stressors have probably led to this shift, including frequent hurricanes, increased sedimentation and nutrient loading related to coastal development, direct physical damage to reef structure due to vessel groundings and other human contact (FKNMS SAC 2004), disease, bleaching and the associated mortality of stony corals and other invertebrates (Santavy et al. 2001), which has created open substrate for macroalgal recruitment (Williams et al. 2001), and herbivore decline, particularly density fluctuations and the eventual near absence of the black spiny urchin Diadema antillarum, which has resulted in decreased macroalgal grazing (Hay 1984, Aronson \& Precht 2000, Bellwood et al. 2004).

Intensive fishing throughout the Caribbean region has driven declines in targeted reef fish abundance, size and diversity (Bohnsack et al. 1994, Ault et al. 1997). Grouper and snapper are commonly targeted (Bohnsack et al. 1994), and many species are particularly susceptible to overfishing due to their slow growth rates, late age of maturity, protogynous hermaphroditism and predictable adult movement patterns, such as spawning aggregations (Bohnsack 1994). Grouper and snapper function as key predators on reefs, and their intensive removal alters trophic structure and can trigger topdown cascades in the reef community (Pinnegar et al. 2000, Valentine \& Heck 2005, Mumby et al. 2006).

Marine protected areas have become an increasingly common fisheries and reef management tool (Roberts \& Polunin 1991, Sobel \& Dahlgren 2004). Protected area research typically focuses on improve- 
ments to local fisheries and, in most cases, the establishment of well-enforced and fully protected reserves has led to increased targeted fish and invertebrate abundance, diversity and mean size (Polunin \& Roberts 1993, Sobel \& Dahlgren 2004). In response to signs of reef decline in the Florida Keys, the $9515 \mathrm{~km}^{2}$ Florida Keys National Marine Sanctuary was established in 1990. Fishing and recreational use is permitted throughout the sanctuary except within 24 non-consumptive zones (Special Protected Areas or SPAs) established within the sanctuary in 1997 (Dept of Comm., NOAA 1997).

Only a few studies have considered the indirect effects of marine reserve establishment on non-target fish, invertebrates and the benthos (Watson \& Ormond 1994, McClanahan 2000, Shears \& Babcock 2003, Mumby et al. 2006). Predator restoration within reserves may drive important dominance shifts in other key functional groups, such as herbivorous fish and reef-building corals (Fig. 1). Regulations and enforcement of protected areas may reduce or eliminate physical contact with the reef, including vessel groundings and other anthropogenic contact, and also eliminate damage to corals and other benthic organisms from fishing equipment and destructive harvest techniques. These regulations may also drive an increase in tar-

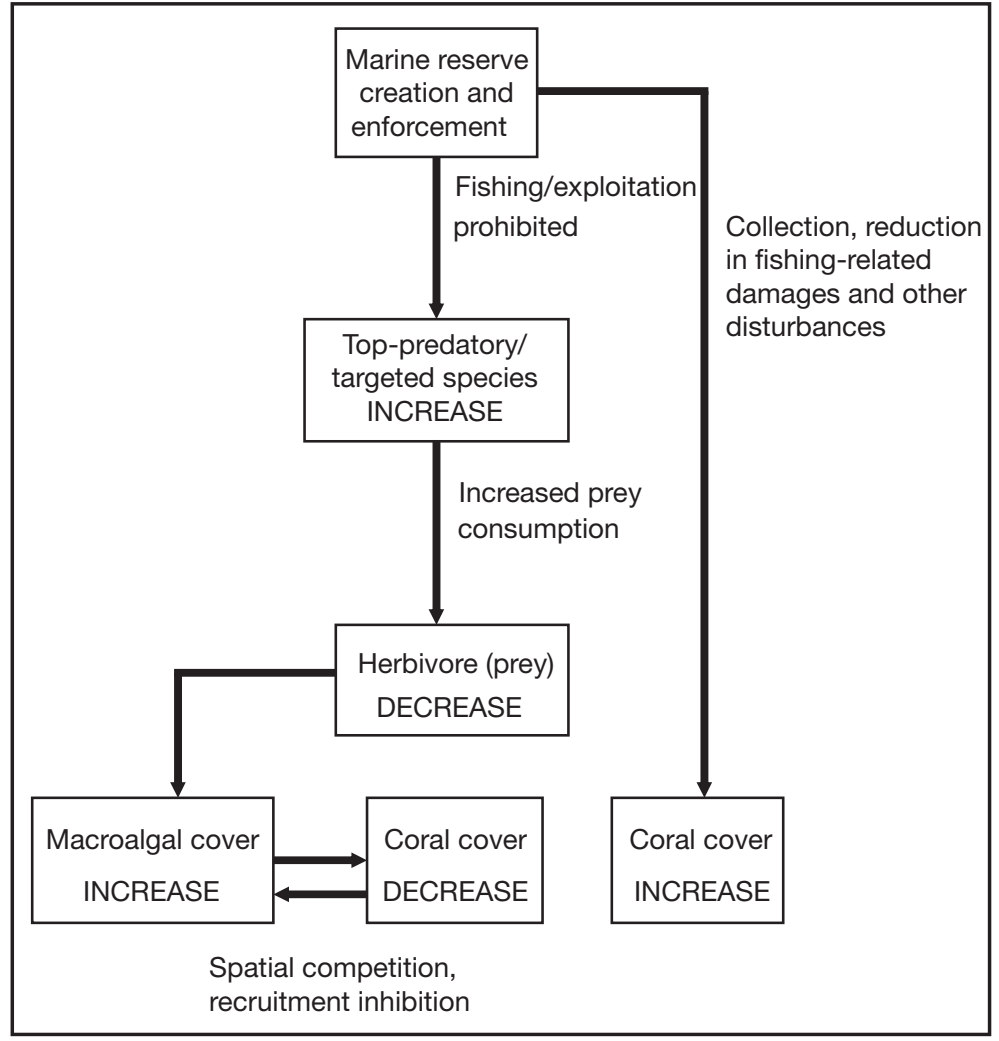

Fig. 1. Model of the potential effects of marine reserve protection on coral patch reef community structure geted top-predators within protected areas, which then increasingly consume herbivorous prey fish. The subsequent reduction in herbivory and grazing potentially encourages macroalgal survivorship and growth, indirectly driving coral decline by intensifying spatial competition with adult colonies and by precluding larval settlement (Fig. 1). This model of a top-down trophic cascade is unique to the Florida Keys because herbivorous fish are not targets of fishing, unlike most other areas in the Caribbean. Hence, marine reserve establishment is unlikely to directly cause an increase in herbivore abundance. Instead, herbivore assemblages are more likely to be indirectly affected by increased predation.

The goal of this study was to investigate whether the establishment of SPAs led to altered community structure on patch reefs in the Florida Keys National Marine Sanctuary. The specific goals were to determine if (1) targeted/predatory reef fish biomass and size were increased in protected areas, (2) herbivorous fish abundance and grazing intensity decreased in protected areas, and (3) benthic assemblages were distinct on protected and reference reefs (including benthic cover and juvenile coral abundance).

\section{MATERIALS AND METHODS}

Site selection and similarity. In June 1997 the National Oceanographic and Atmospheric Administration (NOAA) created the controversial Zoning Action Plan, which established 24 non-consumptive zones, or SPAs, in the Florida Keys (Suman et al. 1999). Within these zones, regulations prohibit all consumptive activities and physical contact with any organism. The sites selected by NOAA for special protection are widely variable in size and reef type and include 10 well-developed forereef areas, 7 inshore patch reefs, 6 offshore patch reef/hardbottom areas, and 1 large, continuous 'ecological reserve' that includes inshore reefs, seagrass and hardbottom areas and offshore reefs. The SPAs (not including the ecological reserve) typically only cover relatively well-developed reefs and average about $0.51 \mathrm{~km}^{2}$ in size.

Because most spur-and-groove reefs in the Florida Keys are protected, patch reefs provide a unique opportunity to compare protected reefs with similar fished reference reefs. Three protected patch reefs were selected, 2 from the Newfound Harbor SPA and one from the 
Looe Key Special Use Area (SUA). The patch reefs within the Newfound Harbor SPA are surrounded by moorings for recreational users and are heavily visited year round by snorkelers, including frequent visits by large summer camp groups. Public entry is prohibited within the Looe Key SUA. Sanctuary officers at all selected SPA reefs strictly enforce non-consumptive regulations. Two reference patch reefs (REF) were selected to the east and southeast of the Newfound Harbor SPA. These sites are heavily fished, typically via hook-and-line and spearfishing techniques (Fig. 2).

Protected and reference patch reefs were selected to minimize variability related to site differences by matching depth range, reef size, topographic complexity, distance from shore and distance from the forereef, as closely as reasonably possible. Reef depth and size were estimated during transect surveys, and a nautical chart was used to estimate the distance from each reef to the shore and forereef. Topographic complexity was estimated by determining an average rugosity ratio (R) for each site (Luckhurst \& Luckhurst 1978). Using 4 replicates of a $21 \mathrm{~m}$ small loop (7 mm) brass chain placed along reef contours, $\mathrm{R}$ was calculated as an average of the straight line horizontal distance along the reef divided by the contour distance (see Table 2).
Targeted/predatory and herbivorous reef fish. Transect surveys were used to quantify the abundance and biomass of targeted/predatory fish (grouper [Serranidae] and snapper [Lutjanidae]), and the abundance and size-class of non-targeted herbivorous fish, including surgeonfishes (Acanthuridae), damselfishes (Pomacentridae) and parrotfishes (Scaridae). Before surveys began, observers learned to accurately estimate fish length by recognizing 8 known lengths (between 15 and $100 \mathrm{~cm}$ ) of PVC piping underwater at varying distances (Bell et al. 1985). Fish surveys were not conducted on days with low visibility $(<2 \mathrm{~m})$ and/or rough weather conditions.

Grouper and snapper were counted along three $25 \times$ $5 \mathrm{~m}$ belt transects on 5 to 6 haphazardly selected days from June through September 2004 (Table 1). All 'targeted' fish individuals within the belt were identified to species and their lengths estimated. Athough not every crack and crevice was investigated, visible tails and fins within the belt were pursued and identified.

Herbivorous fish abundance and size-class were estimated using $20 \times 1 \mathrm{~m}$ transect surveys. A count and size category (based on estimated length and phase coloration) was recorded for each individual. For parrotfish, size categories were assigned based on both size and coloration, and each fish was categorized as a juvenile $(<10 \mathrm{~cm})$, initial phase adult $(10-18 \mathrm{~cm})$, or terminal phase adult $(>18 \mathrm{~cm})$. Acanthurids and pomacentrids were classified as either juveniles $(<6-8 \mathrm{~cm})$ or adults $(>6-8 \mathrm{~cm})$ based on size and coloration. Phase coloration was the primary means of determining size-class and values very rarely fell outside of the estimated size ranges listed above. Each reef was sampled with 3 transects $\mathrm{d}^{-1}$ on 7 to $9 \mathrm{~d}$ from June through September of 2003 and 2004 (Table 1). Transects were typically placed starting at an edge of the patch reef and heading towards its center along the top, contoured slightly with the reef topography. Each reef, therefore, received the same amount of 'edge' and 'top' sampling. Transects occasionally passed over small grooves containing sand and rubble, but never traversed into continuous sand or seagrass habitats.

Herbivory. Seagrass and macroalgal tethers were deployed on each reef to directly measure grazing intensity. We selected high-nitrogen seagrass Thalassia testudinum and 2 species of fleshy red algae, Acanthophora spici-
Fig. 2. Selected patch reef sites in the Florida Keys National Marine Sanctuary $\mathrm{SPA}=$ Special Protected Area, REF = reference patch reef 


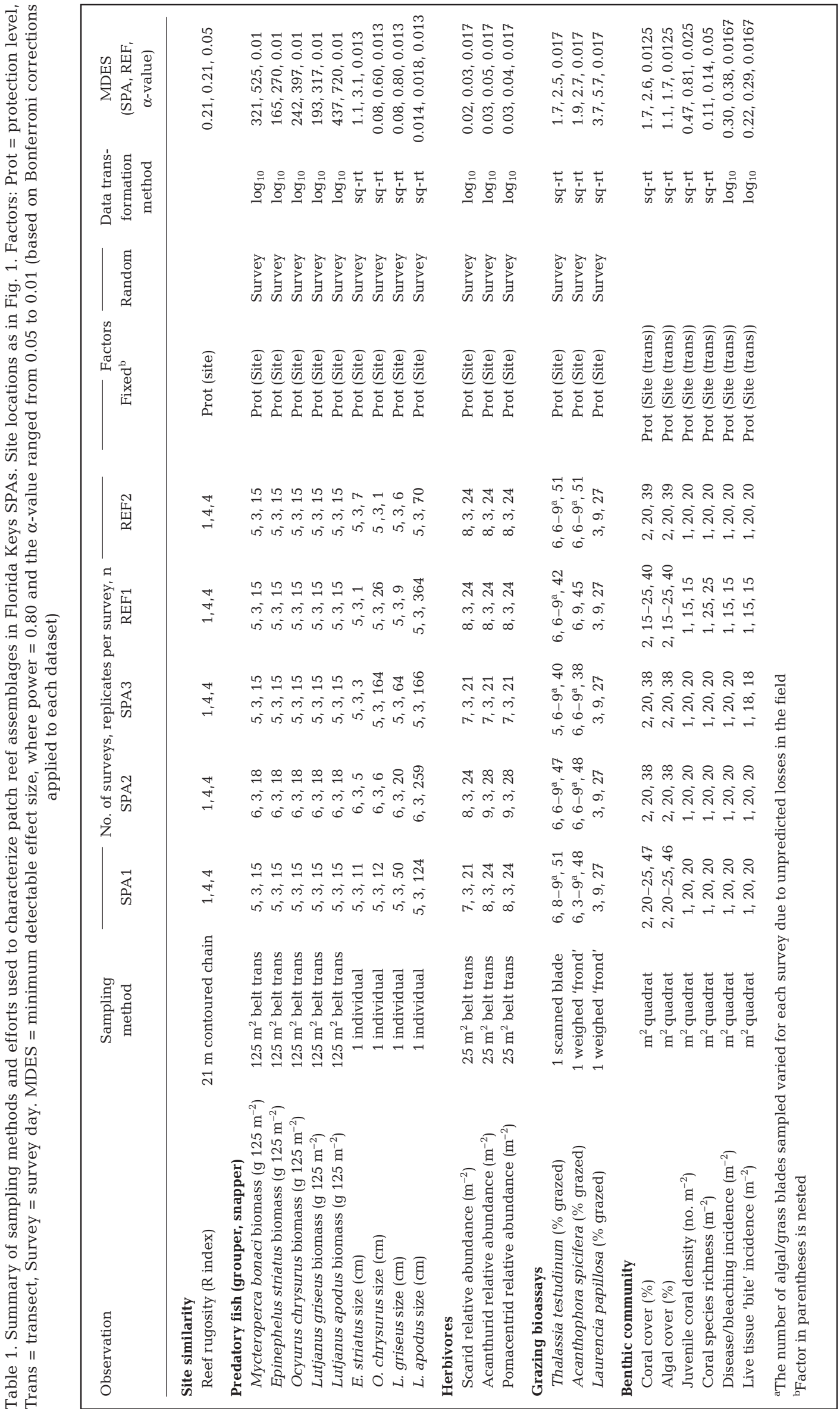


fera and Laurencia papillosa, to use for grazing bioassays based on their local availability and high palatibilities (Hay 1984, Lewis 1986, Goecker et al. 2005). Thalassia testudium was collected in canals surrounding Little Torch Key and A. spicifera and L. papillosa were collected in nearby inshore areas no more than $24 \mathrm{~h}$ before deployment. Epiphytes were gently removed from all samples by hand. Wet $A$. spicifera and $L$. papillosa samples (of about $5 \mathrm{~g}$ ) were spun with an OXO Salad Spinner for 15 revolutions, weighed and attached to $0.5 \mathrm{~m}$ lengths of rope with wooden clothespins. Samples of T. testudinum (usually 3 leaves) were digitally photographed between 2 pieces of clear Plexiglass and similarly attached to ropes. Each tether contained 3 same-species samples and was haphazardly deployed at each reef for $3 \mathrm{~h}( \pm 15 \mathrm{~min})$. After collection, all samples were immediately weighed or photographed. Thalassia testudinum photographs were analyzed with SigmaScanPro (Systat), which estimated 'pre' and 'post' blade area. In 2004 each reef received 3 sets of 3 shoots of $T$. testudinum and A. spicifera on each of 6 survey days from June through August (Table 1). Laurencia papillosa grazing experiments were also included on 3 of these 6 survey days (Table 1).

To control for losses in weight and area associated with deployment and/or wave action, a control set of each species was caged at each site. Mesh size $\left(1 \mathrm{~cm}^{2}\right)$ was small enough to exclude most fish herbivores, yet large enough to allow most wave energy. Acanthophora spicifera and Laurencia papillosa controls consistently lost weight (at an average of 8.0 and $10.2 \%$, respectively), and these mean percent losses were subtracted from observed losses in experimental tethers. Thalassia testudinum control samples had no observed losses in control experiments.

The herbivorous spiny urchin Diadema antillarum remains uncommon throughout most of the Florida Keys. To verify this, D. antillarum and other urchins (Echinometra spp.) were counted during benthic surveys at each site.

Benthic community composition. In June 2003 and 2004, four $20 \mathrm{~m}$ transect lines were arbitrarily positioned on each reef, and 5 quadrat locations on either side of the line were randomly selected. A $1 \mathrm{~m}^{2}$ quadrat with 12 evenly spaced cross-lines was placed at each of these locations and the organism below each cross-line was characterized (Table 1). Scleractinian corals were identified to species and all other groups were broadly categorized. Additionally, in 2003 coral density (mean no. colonies $\mathrm{m}^{-2}$ ) and diversity (mean no. species $\mathrm{m}^{-2}$ ) were recorded. Benthic inhabitant data were converted to percent cover for each quadrat and then averaged by site. Benthic taxa with mean cover averaging less than $10 \%$ of the total cover (including coralline algae, zoanthids, gorgonians and sponges) were not specifically analyzed. Algal cover was analyzed separately for turf ('fine turf algae' and 'thick turf algae'), upright calcareous algae ('green calcareous algae' and 'red calcareous algae') and upright fleshy algae ('green frondose algae,' 'brown frondose algae' and 'red frondose algae').

In 2004, simple estimates of coral health were recorded during quadrat surveys. The incidence of scleractinian coral disease and/or bleaching and live coral tissue 'bites' were recorded categorically as either 'present' (1) or 'absent' (0) (per $\mathrm{m}^{2}$ quadrat) (Table 1). Disease and/or bleaching was characterized as 'present' if a freshly diseased or necrotic region was visible (such as a black band) or if polyps were abnormally transparent on any colony within the quadrat. Live coral tissue bites were characterized as small, bite-like, white 'scratches' with flattened and/or damaged coral skeletal material.

Juvenile coral abundance. Juvenile corals were quantified during benthic quadrat sampling in 2004 (Table 1). After benthic assessments, each quadrat was first cleared of loose sediment, then thoroughly searched for juvenile corals with diameters $<4 \mathrm{~cm}$. If possible, corals were identified to species.

Because of the frequent and ambiguous partial mortality of corals at all sites, drawing a clear distinction between juveniles and partial adults was often difficult. Also, relatively small, slow-growing taxa, including Favia fragum, Siderastrea radians, Stephanocoenia mechellini and cup coral species, were prevalent at some sites. Based on these ambiguities, 'conservative' and 'liberal' classifications of juveniles were made. Liberal juvenile counts included all corals $<4 \mathrm{~cm}$ in diameter, including possible, but not obvious, partial mortality remnants (usually Montastrea annularis and $S$. mechelinii) and small coral species ( $F$. fragum and $S$. radians). Conservative juvenile counts excluded the small species listed previously and any possible remnants of partial mortality.

Statistical analysis. Table 1 summarizes sampling design, replication, applied transformations, fixed and random factors, applied transformations, $\alpha$-values and minimum detectable effect sizes (MDES) for each dataset. Each dataset was tested for normality and homogeneity of variance (Levene's test), and if needed, was transformed $\left(\log _{10}\right.$, square-root) to correct for failed assumptions. Rugosity (R) was compared between sites using a 1-way ANOVA and Tukey's multiple comparison tests. Fish body length datasets were compared with a 1-way nested (hierarchical) ANOVA with level of protection (SPA or REF) as a fixed factor and individual sites nested within protection level. Fish lengths and abundances were converted to biomass using published length-weight relationships for each 
species (Bohnsack \& Harper 1988). Relative fish abundances, biomass, grazing intensity ( $\%$ loss), coral juvenile densities, coral species richness and coral colony density were compared using a 2-way nested ANOVA with protection level as a fixed factor, individual sites nested within protection level and survey day as a random factor. Coral cover and the 3 categories of algal cover were compared with a nested 2-way ANOVA with protection level and year as fixed factors (sites were nested within protection level and transects were nested within sites). This approach was also used to analyze nominal-scale datasets including the presence/absence of coral disease, partial mortality and live tissue bites. A Kruskal-Wallis nonparametric test was also applied to confirm results for these nominalscale datasets (data were pooled for SPAs and REFs). Bonferroni corrections (adjusted $\alpha$-values) were applied to datasets treated with multiple ANOVAs to control for Type 1 error. For each dataset, a minimum detectable effect size (MDES) was calculated based on a power of 0.80 and an $\alpha$-value dependent on the applied Bonferroni corrections (Table 1).

\section{RESULTS}

Site similarity. Substrate R was not significantly different among sites. Comparisons of other parameters also indicated that the selected sites were similar (Table 2).

Targeted/predatory reef fish. The most common targeted groupers observed in surveys were black grouper Mycteroperca bonaci and Nassau grouper Epinephelus striatus. Commonly encountered snapper species were schoolmaster Lutjanus apodus, yellowtail snapper Ocyurus chrysurus and gray snapper L. griseus. Targeted species that were rarely encountered include the mahagony snapper $L$. mahogoni, dog snapper $L$. jocu and mutton snapper $L$. analis. Goliath grouper $E$. itajara, yellowfin grouper $M$. venenosa and red grouper E. morio were occasionally observed at some sites, but were never counted in surveys.

Mean biomass (g $125 \mathrm{~m}^{-2}$ ) was significantly greater for black grouper and yellowtail snapper within SPAs (Fig. 3). Yellowtail and schoolmaster snapper biomass varied significantly by site. Mean body length was significantly greater in protected areas for schoolmaster snapper and yellowtail snapper (Table 3). All species varied significantly by site (Table 3). Very
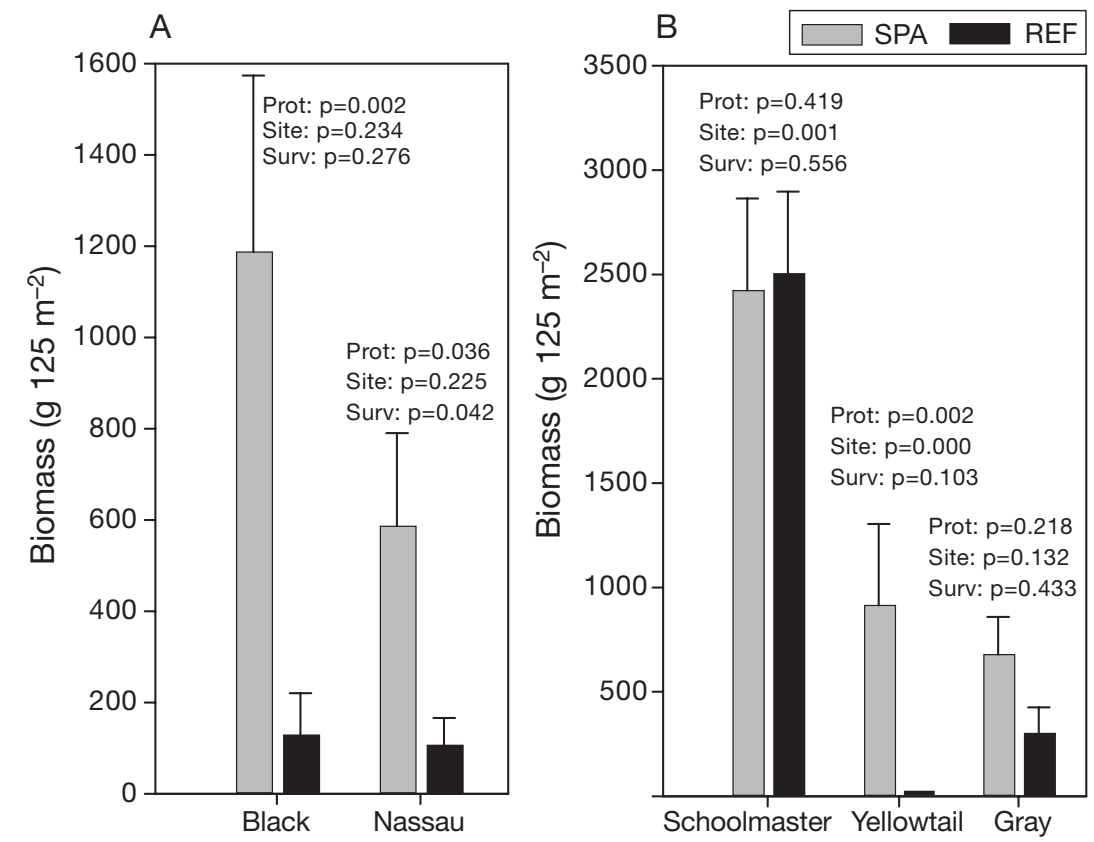

Fig. 3. Mean biomass for (A) grouper (Serranidae) and (B) snapper (Lutjanidae) species observed in underwater transect surveys; $p$-values listed for each factor related to biomass: protection level (Prot), site and survey day (Surv), see Table 1

Table 2. Summary of selected patch reef site similarity. Standard errors and the number of replicates (n) are given in parentheses below mean values for rugosity (R)

\begin{tabular}{|c|c|c|c|c|c|c|}
\hline \multirow{2}{*}{ Site similarity } & \multicolumn{5}{|c|}{ - Site. } & \multirow{2}{*}{$\mathrm{p}$} \\
\hline & SPA1 & SPA2 & SPA3 & REF1 & REF2 & \\
\hline Reef type & $\begin{array}{l}\text { Inshore } \\
\text { patch reef }\end{array}$ & $\begin{array}{l}\text { Inshoref } \\
\text { patch reef }\end{array}$ & $\begin{array}{c}\text { Lagoonal aggregated } \\
\text { patch reef }\end{array}$ & $\begin{array}{l}\text { Inshore } \\
\text { patch reef }\end{array}$ & $\begin{array}{c}\text { Inshore aggregated } \\
\text { patch reef }\end{array}$ & - \\
\hline Depth (m) & $0.6-2.1$ & $0.6-2.4$ & $4.9-7.6$ & $2.1-4.0$ & $2.1-4.9$ & - \\
\hline Mean R & 0.593 & 0.600 & 0.698 & 0.566 & 0.650 & 0.154 \\
\hline$(\mathrm{SE}, \mathrm{n})$ & $(0.05,4)$ & $(0.03,4)$ & $(0.04,4)$ & $(0.01,4)$ & $(0.02,4)$ & \\
\hline Distance to shore (m) & 692 & 648 & 6057 & 1194 & 1155 & - \\
\hline Distance to forereef (m) & 7280 & 7240 & 2040 & 6800 & 6720 & _- \\
\hline Reef size $\left(\sim \mathrm{m}^{2}\right)$ & 10000 & 7500 & 20000 & 900 & 7500 & - \\
\hline SPA size $\left(\sim \mathrm{km}^{2}\right)$ & 0.27 & 0.27 & 0.62 & - & - & - \\
\hline
\end{tabular}


low abundances of the black grouper in REFs prevented a reliable comparison of body length between sites.

Size-frequency distributions were constructed for the most common fish species observed in transect surveys (Fig. 4). Estimated body lengths for each observed fish individual were pooled to create each distribution. Typically, fish larger than the recreational size limit were only observed within SPAs, and size distributions tended to be right-skewed for SPAs relative to reference areas for the most common predatory fish species (Fig. 4).

Herbivore abundance. Diadema antillarum were never observed in surveys. Echinometra spp. (usually E. viridis) were only occasionally observed at Site REF2. Individuals were found within crevices or bored holes on the reef and were typically surrounded by thick fleshy and calcareous macroalgae (e.g. Dictyota spp. and Halimeda spp.). Evidence of grazing around crevices was never observed, and Echinometra spp. are generally not thought to be strong grazers of exposed reef substrates (McClanahan 1999). Based on these surveys, herbivorous fish were assumed to be the primary herbivores at all sites.

Analysis of herbivorous fish abundance by sizeclass/phase for each family showed that adult scarids (including initial and terminal phases) and adult pomacentrids (larger size-class) were significantly more abundant within SPAs. Juvenile scarids and pomacen-

Table 3. Summary statistics for targeted/predatory fish mean body lengths $(\mathrm{cm})$ observed in transect surveys. $\mathrm{ns}=$ not significant, ${ }^{*}=$ significant

\begin{tabular}{|lccrl|}
\hline $\begin{array}{l}\text { Targeted species } \\
\text { body length }\end{array}$ & df & MS & $F$ & $\mathrm{p}$ \\
\hline Nassau grouper & & & & \\
Protection & 1 & 0.028 & 4.11 & $0.058, \mathrm{~ns}$ \\
Site (Protection) & 3 & 0.054 & 7.65 & $0.002^{*}$ \\
Survey day & 4 & 0.013 & 1.86 & $0.162, \mathrm{~ns}$ \\
Error & 18 & 0.007 & & \\
Gray snapper & & & & \\
Protection & 1 & 0.049 & 5.93 & $0.016, \mathrm{~ns}$ \\
Site (Protection) & 3 & 0.128 & 15.37 & $0.000^{*}$ \\
Survey day & 4 & 0.060 & 7.19 & $0.000^{*}$ \\
Error & 140 & 0.008 & & \\
Yellowtail snapper & & & & \\
Protection & 1 & 0.120 & 11.76 & $0.001^{*}$ \\
Site (Protection) & 3 & 0.061 & 5.95 & $0.001^{*}$ \\
Survey day & 3 & 0.040 & 3.88 & $0.010, \mathrm{~ns}$ \\
Error & 201 & 0.010 & & \\
Schoolmaster snapper & & & & \\
Protection & 1 & 723.2 & 28.74 & $0.000^{*}$ \\
Site (Protection) & 3 & 408.5 & 16.23 & $0.000^{*}$ \\
Survey day & 4 & 115.0 & 4.57 & $0.001^{*}$ \\
Error & 974 & 25.2 & 25.16 & \\
\hline & & & & \\
\hline
\end{tabular}

trids (smaller size-classes) were significantly less abundant in SPAs (Fig. 5). Acanthurid abundances were not related to protection level.

Herbivory. Observed grazing intensity was unrelated to protection level for all plant species (Fig. 6, Table 4). Grazing differences varied significantly by site for Thalassia testudinum and Laurencia papillosa, and varied significantly by survey day for $T$. testudinum and Acanthophora spicifera (Fig. 6, Table 4).

Benthic community composition. There were no significant differences in percent algal cover (turf, fleshy macroalgae, upright calcareous) related to protection; differences were significantly site-specific for turf and upright calcareous algae (Fig. 7A-C). Between years, coral cover was consistently and significantly lower in SPAs than in REFs (Fig. 7D).

Juvenile coral abundance and coral health. Coral juvenile abundance was significantly site-specific for both liberal and conservative density estimates and was not related to protection (Table 5, Fig. 8). The 2 methods used to estimate juvenile density yielded proportionally similar relative differences between sites (Fig. 8). Site SPA3 consistently had the highest juvenile density (Fig. 8).

Coral species richness was significantly related to protection and was significantly higher in REFs (Table 5). Species richness also varied consistently with site and transect. The incidence of coral bleaching and disease was unrelated to protection (Table 5). However, the incidence of live coral tissue 'bites' was significantly more common in protected areas and was also significantly related to site (Table 5).

Table 4. Summary statistics for comparisons of mean percentage of area $\left(\mathrm{cm}^{2}\right)$ or weight $(\mathrm{g})$ consumed for experimental grazing bioassays. $\mathrm{ns}=$ not significant, ${ }^{*}=$ significant

\begin{tabular}{|lcccc|}
\hline Bioassay \% consumption & df & MS & $F$ & $\mathrm{p}$ \\
\hline Thalassia testudinum & & & & \\
Protection & 1 & 20.95 & 2.81 & $0.095, \mathrm{~ns}$ \\
Site (Protection) & 3 & 142.3 & 19.1 & $0.000^{*}$ \\
Survey day & 5 & 27.49 & 3.69 & $0.003^{*}$ \\
Error & 221 & 7.45 & & \\
Acanthophora spicifera & & & & \\
Protection & 1 & 1.096 & 0.13 & $0.722, \mathrm{~ns}$ \\
Site (Protection) & 3 & 14.98 & 1.74 & $0.160, \mathrm{~ns}$ \\
Survey day & 5 & 122.4 & 14.19 & $0.000^{*}$ \\
Error & 220 & 8.63 & & \\
Laurencia papillosa & & & & \\
Protection & 1 & 34.33 & 3.9 & $0.050, \mathrm{~ns}$ \\
Site (Protection) & 3 & 169.5 & 19.3 & $0.000^{*}$ \\
Survey day & 2 & 13.82 & 1.57 & $0.212, \mathrm{~ns}$ \\
Error & 128 & 8.81 & & \\
\hline & & & & \\
\hline
\end{tabular}




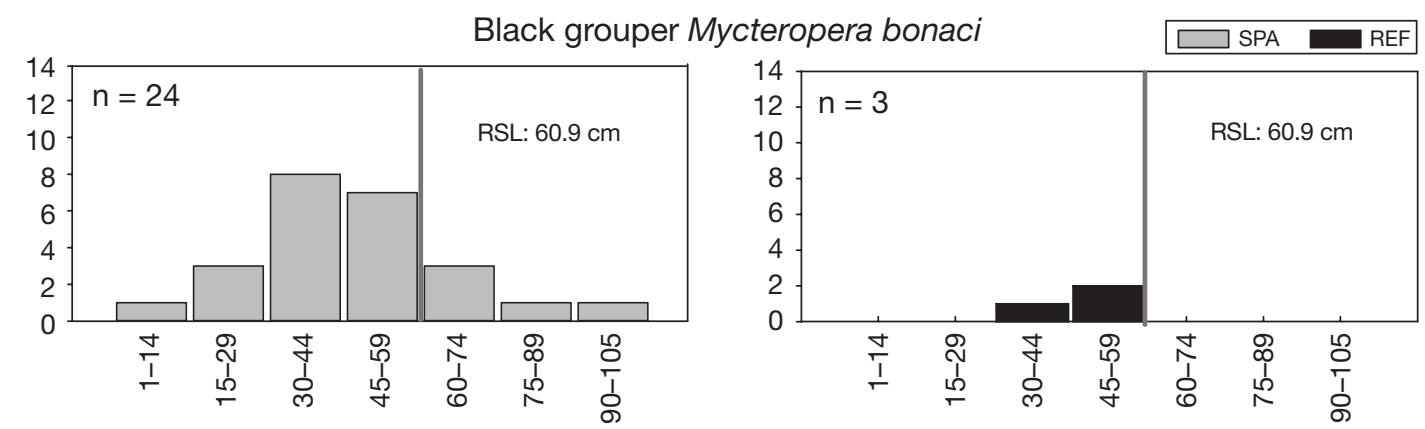

Nassau grouper Epinephelus striatus
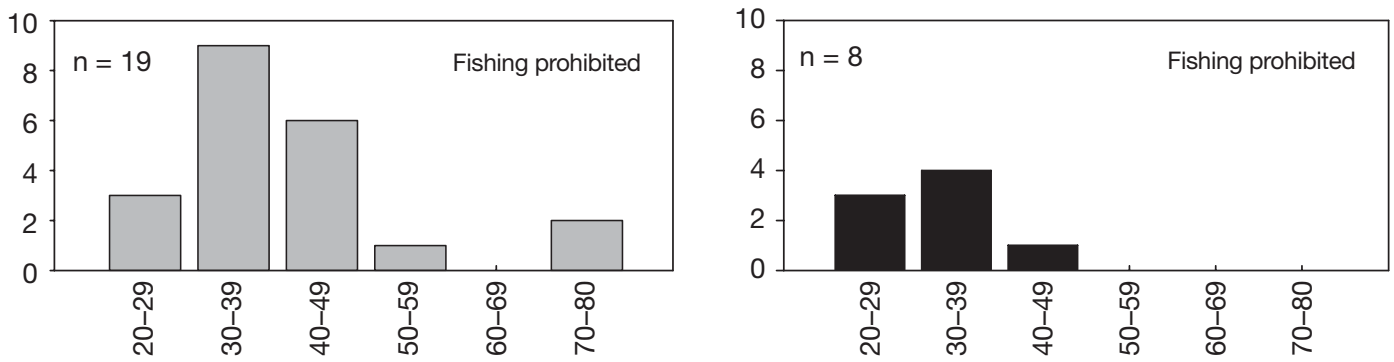

Yellowtail snapper Ocyurus chrysurus
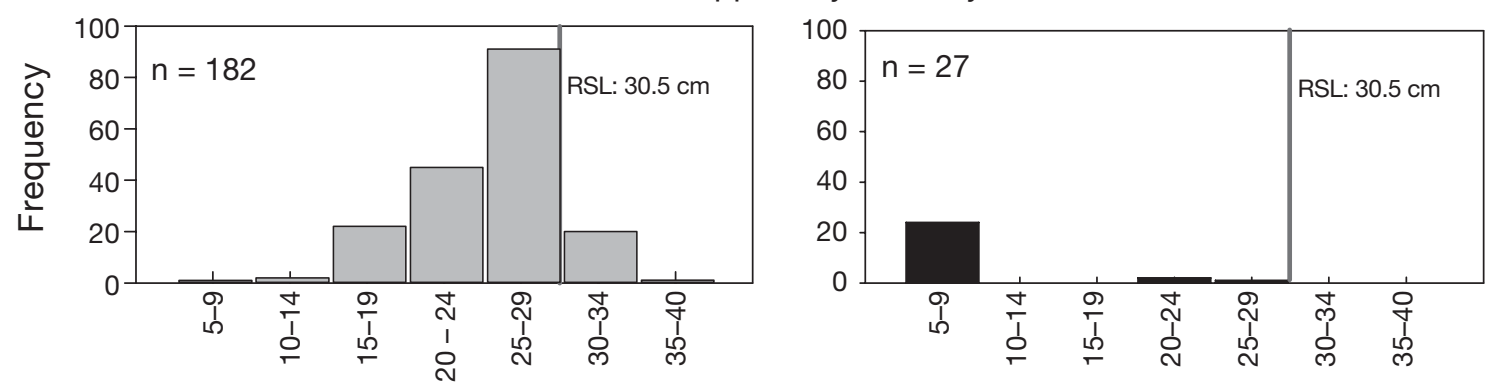

Gray snapper Lutjanus griseus
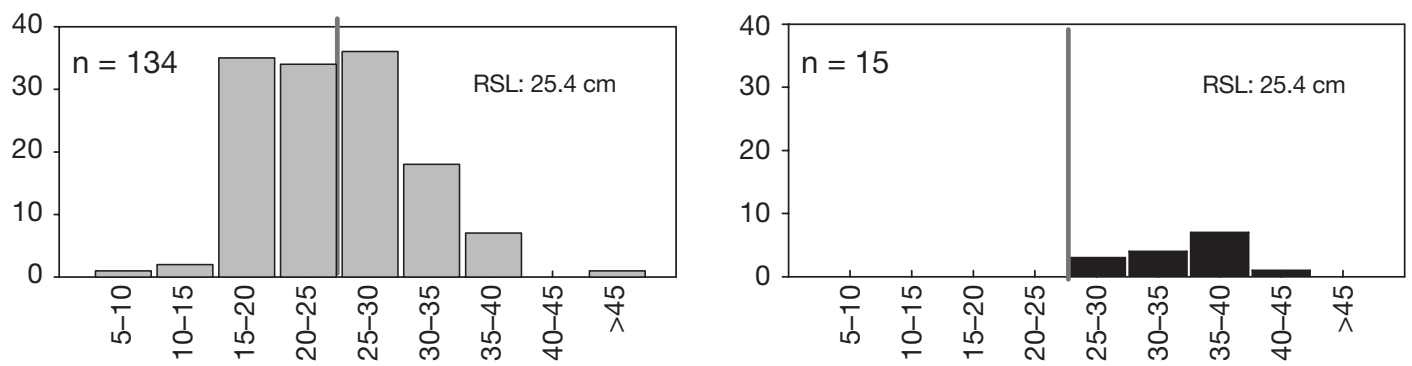

Schoolmaster snapper Lutjanus apodus
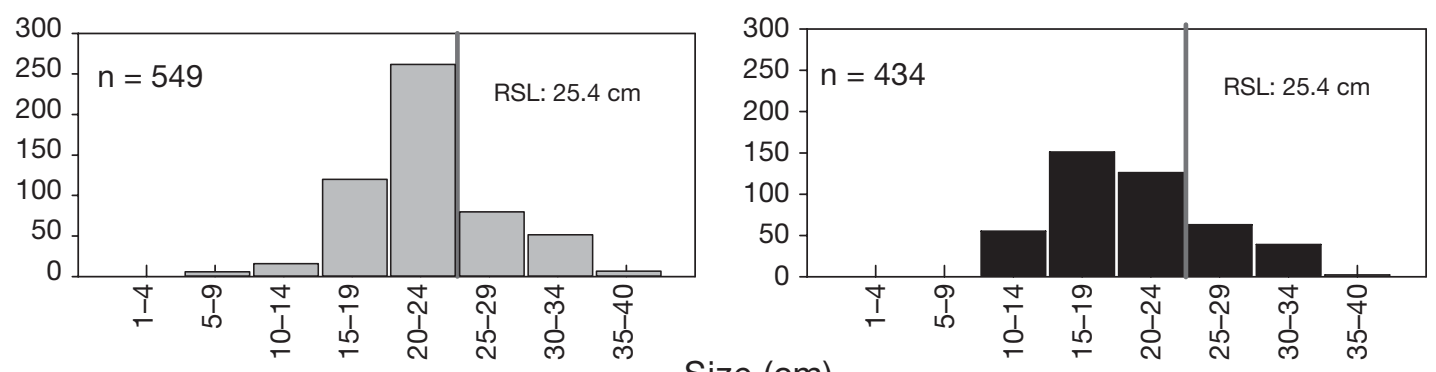

Size $(\mathrm{cm})$

Fig. 4. Body length frequency distributions for commonly observed targeted fish species at SPA (left) and REF (right) patch reefs. The vertical line in each graph indicates the recreational size limit (RSL) for legal harvest 

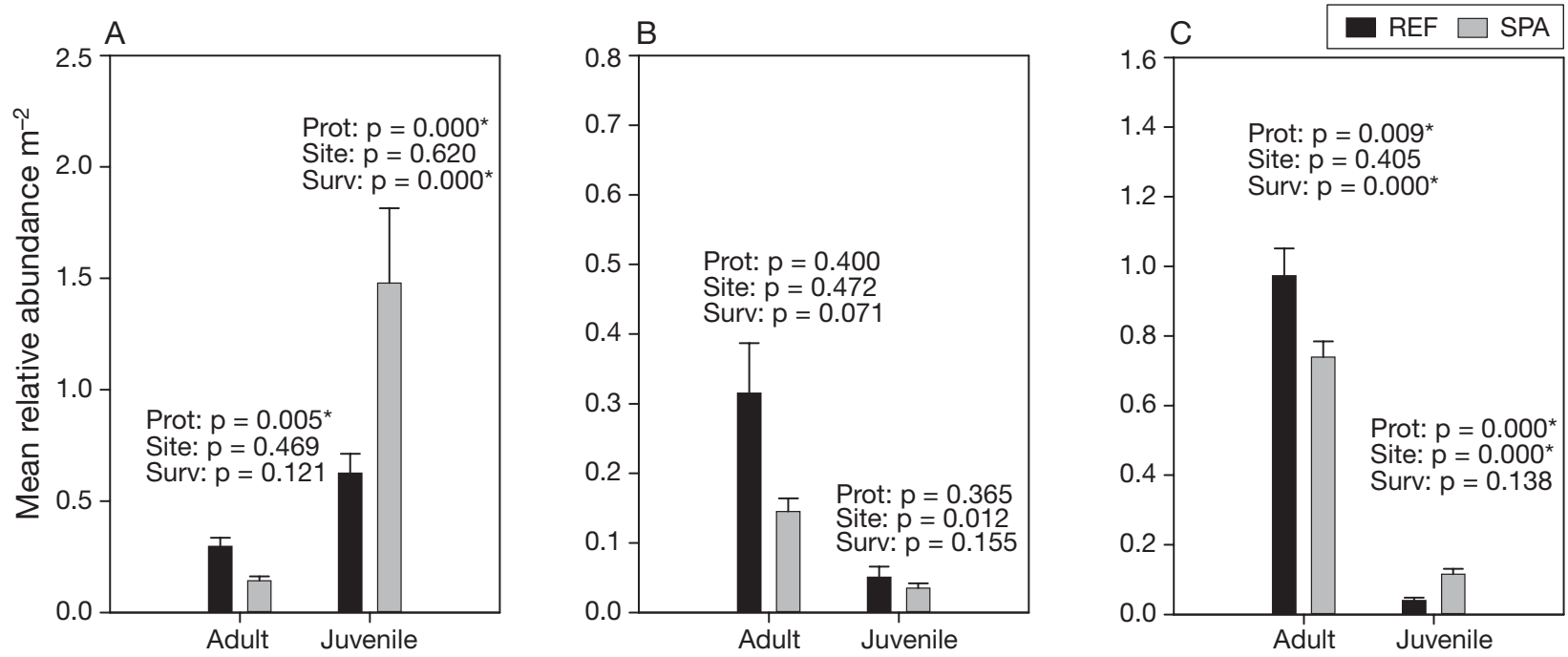

Fig. 5. Mean abundances of (A) scarids, (B) acanthurids and (C) pomacentrids, grouped by life phase; p-values listed for each factor related to herbivore abundance: protection level (Prot), site and survey day (Surv), see Table $1 ;{ }^{*}=$ significant

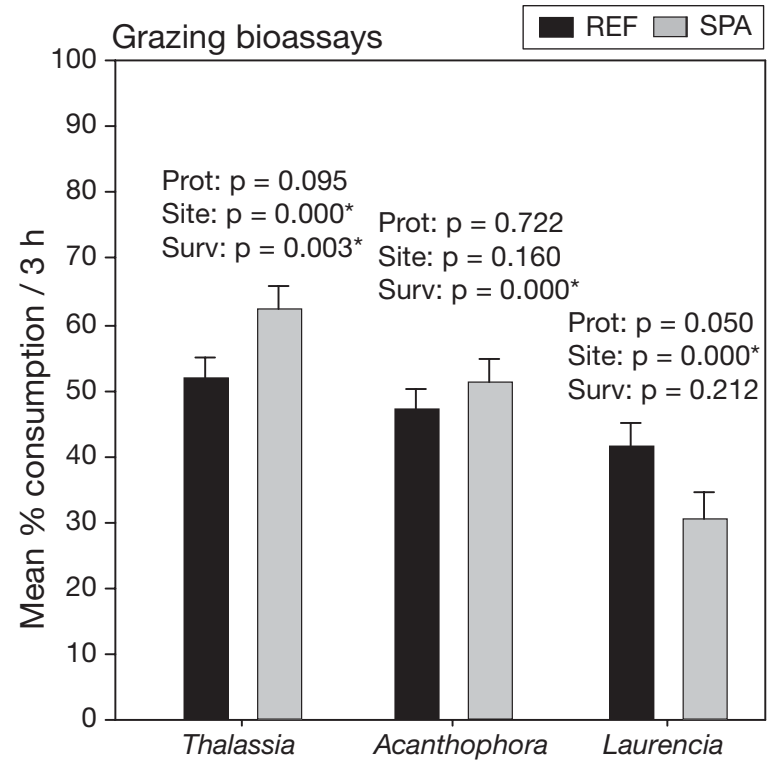

Fig. 6. Mean percent consumption in $3 \mathrm{~h}$ period of seagrass (Thalassia testudinum) and macroalgal (Acanthophora spicifera and Laurencia papillosa) bioassays; p-values listed for each factor related to experimental grazing: protection level (Prot), site and survey day (Surv), see Table $1 ;{ }^{*}=$ significant

\section{DISCUSSION}

In the Florida Keys, protected areas are well funded, well enforced, and generally accepted by the public, although not without debate (Suman et al. 1999). Local residents are knowledgeable about the state of coral reefs and are often personally invested in recovery efforts (e.g. organizations such as Reef Relief). Wellmanaged 'no-take' reserves, such as the SPAs in the
Florida Keys, effectively reduce fishing pressure despite some occasional poaching (FKNMS SAC 2004). This reduction in harvest in protected zones serves as a possible mechanism for the initiation of cascading effects in the reef community (Pinnegar et al. 2000, Valentine \& Heck 2005, Mumby et al. 2006).

This study documents significantly greater biomass and mean body length, and right-skewed size distributions for several common predatory fish species within inshore patch reef SPAs (Table 3, Figs. 3 \& 4). This pattern is probably driven by the reduction of fishing in these areas, which creates a refuge for large targeted fish. Increased biomass and size was not observed for the Nassau grouper, which is probably related to the existing, complete ban of fishing for this species, both inside and outside of SPAs. Although once heavily fished, Nassau grouper Epinephelus striatus harvest is now prohibited throughout the USA. For the other common grouper species, black grouper, and for common targeted snapper species, including yellowtail snapper, gray snapper and schoolmaster snapper, protection has resulted in an increase in mean size and/or biomass within SPAs.

Size-frequency distributions were right-skewed for SPA populations, and individuals larger than the legal size limit were almost never observed in REFs (Fig. 4). Recreational fishing in REFs probably results in these truncated size distributions by removing most large individuals (Stergiou 2002). Concurrent traditional fisheries management (e.g. size limitations) throughout the Florida Keys National Marine Sanctuary has allowed smaller, non-legal size targeted fish to reside in all areas. This has resulted in a similar mean biomass for schoolmaster snapper in SPAs and reference areas (Fig. 3). Still, schoolmaster snapper were significantly larger within SPAs (Table 3). 

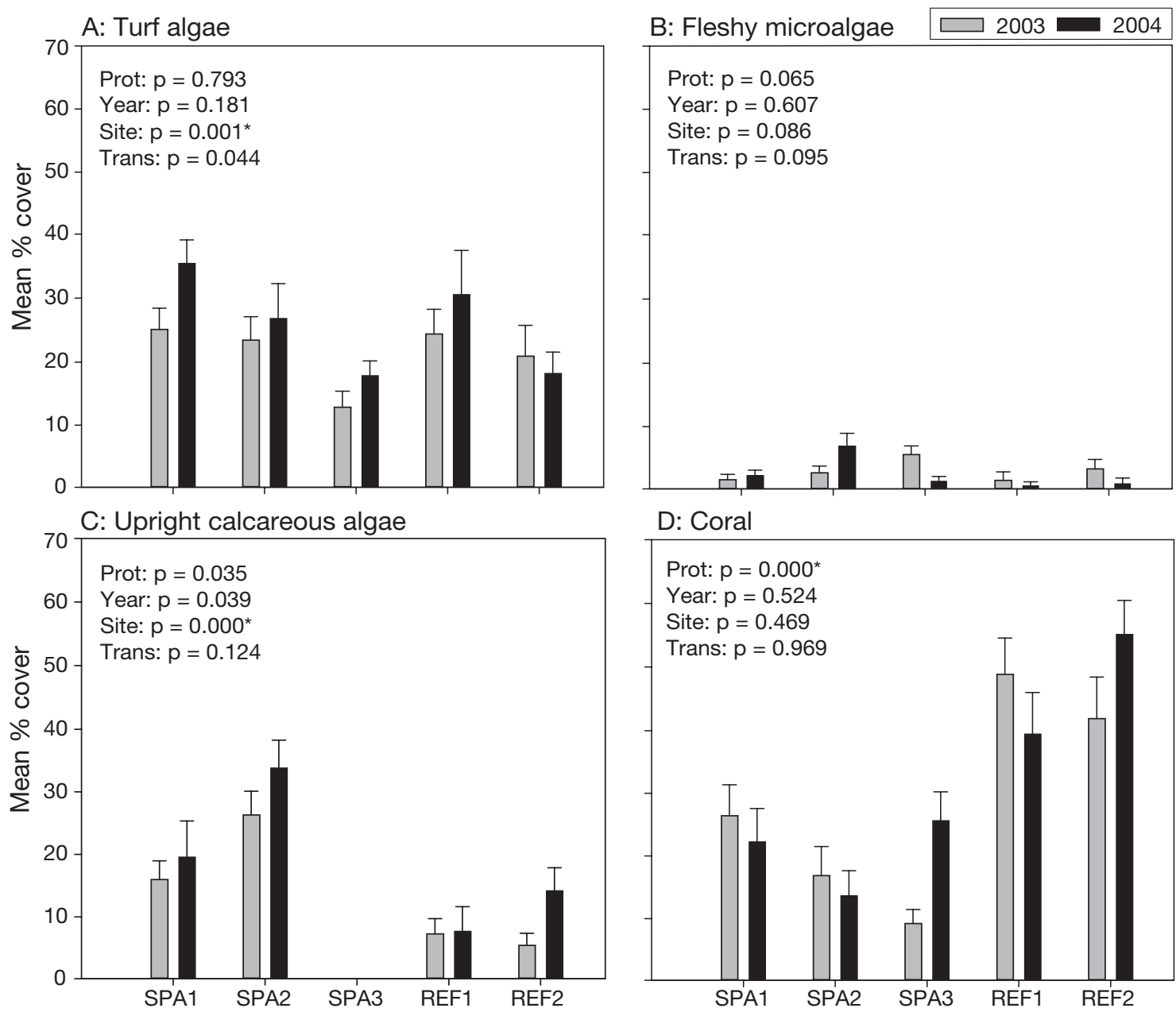

D: Coral

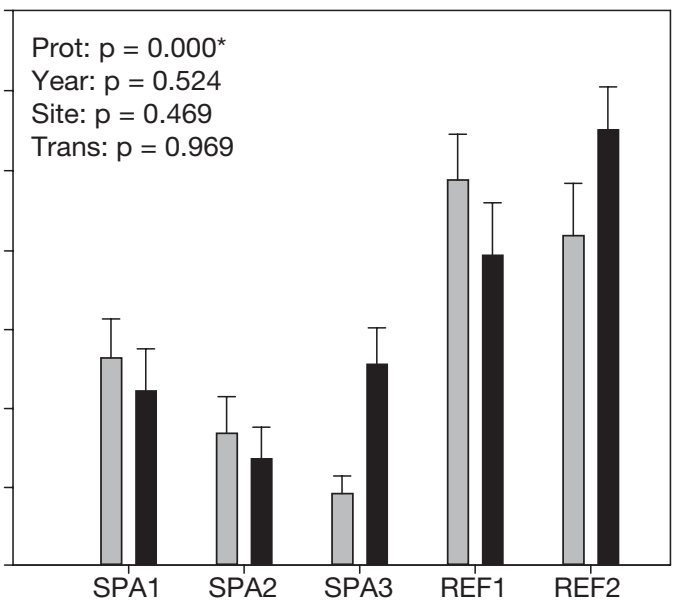

Fig. 7. Percent cover for (A) turf algae, (B) fleshy macroalgae, (C) upright calcareous algae, and (D) coral for each site in 2003 and 2004; p-values listed for each factor related to benthic cover: protection level (Prot), year, site and transect (Trans), see Table $1 ;{ }^{*}=$ significant

Because fecundity increases exponentially with body size (Roberts \& Polunin 1991, Bohnsack 1994), the larger fish individuals residing in SPAs can potentially increase the reproductive output from these areas. For example, a $36.3 \mathrm{~cm}$ red hind Epinephelus guttatus was $278 \%$ more fecund than a $31.0 \mathrm{~cm}$ individual (Roberts \& Polunin 1991). Also, the increased biomass observed for several species suggests that these regions may eventually result in adult fish export to surrounding areas.

Herbivorous fish assemblages were strongly associated with fishing protection, as predicted (Fig. 1), although populations were not affected uniformly. Large adult scarids and pomacentrids were more abundant within SPAs, and small juvenile scarids and pomacentrids were significantly less abundant within SPAs relative to REFs. This size-structure pattern was not observed for acanthurids. These assemblage differences correspond with the findings of Mumby et al. (2006) and may be a result of increased preferential predation by restored predatory fish on smaller, more easily consumed prey. Mumby et al. (2006) found that within the Exuma Cays Land and Sea Park, Bahamas, large parrotfish density and grazing intensity increased dramatically despite the increased threat of predation. After comparing the gape size of groupers common within the reserve, they suggested that parrotfish obtain a size refuge from predation beyond intermediate body lengths. At the sites surveyed in this study, relatively large-bodied parrotfish species were most common, including midnight parrotfish Scarus coelestinus, rainbow parrotfish $S$. guacamaia and stoplight parrotfish $S$. viride. It is likely that average sized individuals of these species would be impossible for an average sized grouper or snapper to consume (Mumby et al. 2006), so despite the increased presence of predators within SPAs, most adult parrotfishes probably escape predation. Concurrently, juvenile parrotfish were significantly less abundant relative to reference assemblages within SPAs. The most likely explanation for this pattern is that predation within reserves is 
Table 5. Summary statistics for coral condition. ns = not significant, ${ }^{*}=$ significant

\begin{tabular}{|c|c|c|c|c|}
\hline Coral condition & $\mathrm{df}$ & MS & $F$ & $\mathrm{p}$ \\
\hline \multicolumn{5}{|c|}{$\begin{array}{l}\text { Coral juvenile density } \\
\text { (no. } \mathrm{m}^{-2} \text { ) (liberal) }\end{array}$} \\
\hline Protection & 1 & 0.475 & 0.5 & $0.482, \mathrm{~ns}$ \\
\hline Site (protection) & 3 & 15.268 & 16.02 & $0.000^{*}$ \\
\hline Transect & 14 & 1.2442 & 1.31 & $0.224, \mathrm{~ns}$ \\
\hline Error & 76 & 0.9529 & & \\
\hline \multicolumn{5}{|c|}{$\begin{array}{l}\text { Coral juvenile density } \\
\left(\text { no. } \mathrm{m}^{-2} \text { ) (conservative) }\right.\end{array}$} \\
\hline Protection & 1 & 0.0697 & 0.1 & $0.751, \mathrm{~ns}$ \\
\hline Site (protection) & 4 & 12.256 & 17.79 & $0.000^{*}$ \\
\hline Transect & 14 & 1.1302 & 1.64 & $0.087, \mathrm{~ns}$ \\
\hline Error & 76 & 0.6891 & & \\
\hline \multicolumn{5}{|c|}{ Coral species richness $\left(\mathrm{m}^{-2}\right)$} \\
\hline Protection & 1 & 1.61 & 9.49 & $0.003^{*}$ \\
\hline Site (protection) & 3 & 6.29 & 37.17 & $0.000^{*}$ \\
\hline Transect & 17 & 0.46 & 2.74 & $0.001^{*}$ \\
\hline Error & 83 & 0.17 & & \\
\hline \multicolumn{5}{|c|}{$\begin{array}{l}\text { Disease/bleaching incidence } \\
\text { (present or absent } \mathrm{m}^{-2} \text { ) }\end{array}$} \\
\hline Protection & 1 & 0.0003 & 0.02 & $0.898, \mathrm{~ns}$ \\
\hline Site (protection) & 3 & 0.0238 & 1.28 & $0.287, \mathrm{~ns}$ \\
\hline Transect & 14 & 0.0418 & 2.25 & $0.013^{*}$ \\
\hline Error & 74 & 0.0186 & & \\
\hline \multicolumn{5}{|c|}{$\begin{array}{l}\text { Live tissue 'bite' incidence } \\
\text { (present or absent } \mathrm{m}^{-2} \text { ) }\end{array}$} \\
\hline Protection & 1 & 0.293 & 23.07 & $0.000^{*}$ \\
\hline Site (protection) & 3 & 0.122 & 9.63 & $0.000^{*}$ \\
\hline Transect & 14 & 0.012 & 0.95 & $0.513, \mathrm{~ns}$ \\
\hline Error & 74 & 0.0127 & & \\
\hline
\end{tabular}

intensified as large predators are more abundant, and the reduction of predators in heavily fished REFs has allowed small herbivorous fish to flourish.

Acanthurids, even as adults, are probably not large enough to preclude predation by a large grouper or

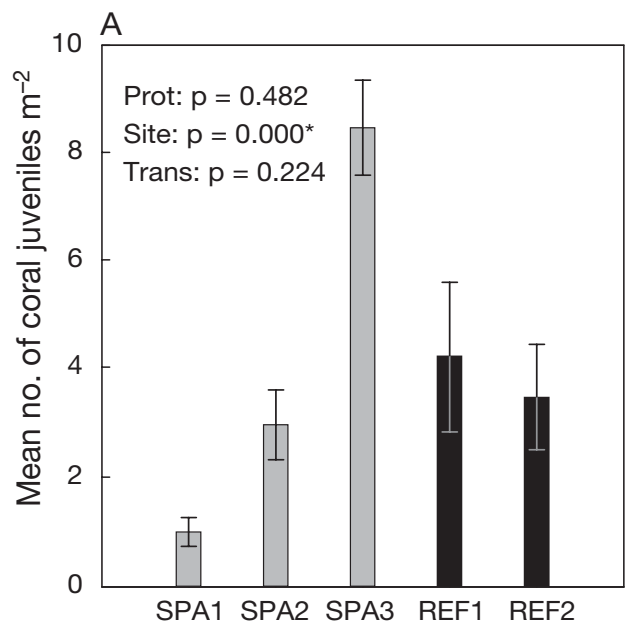

snapper, and no difference in size class abundance was observed for this species (Fig. 5). Pomacentrids, however, shared a size-class abundance pattern similar to scarid assemblages, despite their 'consumable' adult body size (Fig. 5). We suggest that perhaps their intense territorial behavior and extreme awareness of intruders may render adult pomacentrids less likely candidates for predation, despite increased large predator densities within SPAs (Sammarco \& Williams 1982, McCormick \& Holmes 2006). Additionally, the incidence of coral live tissue 'bites' was higher in SPAs (Table 5), and the increased densities of adult pomacentrids were a probable cause.

Differential predation explains the pattern observed for juvenile herbivorous fish, but seemingly larger adult parrotfish and pomacentrids could inhabit both SPAs and REFs without the threat of predation. However, in this study we found that larger size-classes of parrotfish and pomacentrids were significantly more abundant within SPAs. In addition to escaping predation within SPAs, it is possible that large herbivorous fish also benefit from a release from intraspecific competition with juveniles, which were observed at relatively lower abundances within SPAs (Carr \& Hixon 1995).

A general increase in algal cover in SPAs was predicted (Fig. 1) due to an expected reduction in herbivorous fish grazing (Lewis 1986). However, no consistent differences in grazing intensity or macroalgal cover were detected by bioassays and benthic surveys. Possible reasons are that (1) bioassays did not accurately reflect actual grazing intensity (Steneck 1983), (2) increased abundances of large herbivorous fish inside reserves and small herbivorous fish outside reserves may have ultimately resulted in similar grazing inten-

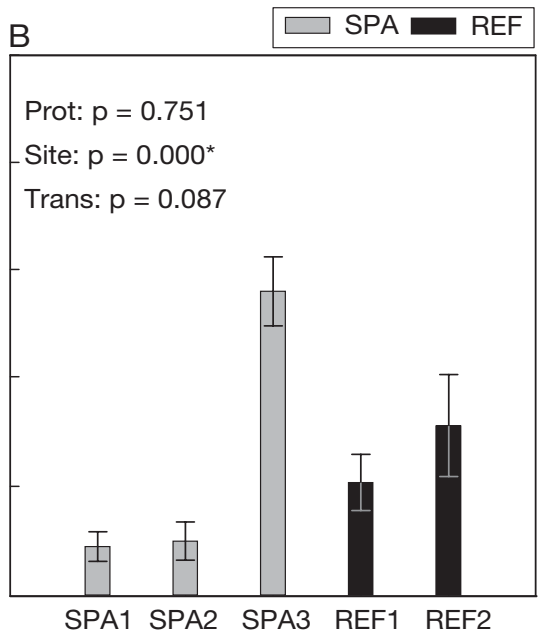

Fig. 8. Juvenile coral densities. Liberal counts (A) included all corals $<4 \mathrm{~cm}$ in diameter, including possible (but not obvious) partial mortality remnants and small coral species. Conservative counts (B) excluded coral species with small adult colony size (such as F. fragum and $S$. radians) and any possible remnants of partial mortality; p-values listed for each factor related to density: protection level (Prot), site and transect (Trans), see Table $1 ;{ }^{*}=$ significant 
sity in SPAs and REFs, (3) grazing intensity and algal cover varied consistently with protection, but differences were at the species level (based on differences in plant preference) and were undetected by the relatively general surveys of algal cover in this study (Bruggemann et al. 1994), or (4) no consistent difference in grazing intensity exists for these sites. Interestingly, relatively consistent patterns of grazing were quantified by bioassays at each site for all tethered species. For example, grazing in Site SPA1 was relatively low for all tethered species, while grazing levels were consistently higher in SPA3. This seems to indicate that the tethers were measuring a real difference in grazing intensity at each site and suggests that grazing intensity was not related to protection.

Another possible explanation for the lack of obvious top-down effects related to grazing intensity and algal cover is the continued absence of a stronger herbivore, the black-spined urchin Diadema antillarum. Herbivorous fish, regardless of their abundance, may not be able to graze as thoroughly and effectively as $D$. antillarum (Hay 1984, Edmunds \& Carpenter 2001, Williams et al. 2001) and may serve as a weak link in a top-down trophic cascade. Herbivorous fish tend to graze selectively and typically avoid certain species, including Halimeda spp. (Bruggemann et al. 1994), which was common at all sites. Despite shifts in herbivorous fish assemblages in SPAs, there seems to be no related differences in grazing and algal cover.

Reef managers and scientists are particularly concerned with the phase shift from coral-dominated to degraded algal-dominated ecosystems (Aronson \& Precht 2000, Bellwood et al. 2004), and marine reserves have been proposed as a means of ensuring coral health (Sobel \& Dahlgren 2004). Coral cover and juvenile abundance were not higher in the studied SPAs (Table 5, Figs. 7D \& 8). Coral cover and species richness were consistently and significantly lower at all 3 SPA reefs compared with REF reefs in both 2003 and 2004. Given the slow growth rate of corals, it is unlikely that this difference in cover arose after SPA establishment, and a multitude of other factors not addressed in this study, such as differences in water quality, sedimentation rates, water flow and larval supply, at least partially controlled benthic assemblages. Yet the relatively close proximity of sites and their general abiotic similarity (Table 1) implies that major ecological factors affecting benthic cover (excluding protection level) are similar between sites. The lack of an observed difference in benthic cover (Fig. 7) suggests that the establishment of these small no-take zones has not immediately resulted in obvious shifts in macroalgal and coral cover.

Given the relatively young age of the studied reserves ( 9 yr since establishment), it is likely that the observed community represents a transitional state.
For example, the large herbivorous fish observed within SPAs were likely resident before reserve establishment and were large enough to escape consumption as predator abundance increased. Once these older cohorts expire, patterns in the herbivorous fish community may reverse due to increased predation of recruits within SPAs. Also, predicted changes in benthic cover related to reserve establishment may simply require more time to materialize because corals and other benthic reef-builders typically grow slowly, and successful growth and recruitment can be highly variable between years (Connell et al. 1997).

By creating a refuge from exploitation, SPA establishment has led to an increase in targeted fish biomass and mean size at the studied inshore patch reefs. This increase in targeted fish assemblages may help to revive the surrounding fishery, and may also have driven shifts in herbivore assemblages by increasing predation on small size-classes. However, the observed shift in the herbivore community was not clearly associated with a difference in grazing intensity, and no obvious differences or 'improvements' were observed in the benthic community. Given the relatively small size and young age of the marine reserves selected for this study, the slow growth of corals and other benthic inhabitants, and the suite of other ecological factors that control benthic assemblages, it is possible that indirect effects of protection on the benthos have not yet occurred or are not yet observable. On the other hand, SPA establishment and the prohibition of fishing may not be a strong enough mechanism to drive shifts in the benthic community. Regardless of regulated resource exploitation within SPAs, the fluid nature of the marine environment allows pollutants, pathogens and high temperature water from surrounding areas into reserve zones. Additional management in conjunction with reserve protection may still be needed, such as more rigorous water quality regulations in the Florida Keys and the Florida peninsula. Without protection-induced benefits, stony coral populations are relying solely upon natural recruitment and slow growth for recovery, and the continued decline of coral populations may eventually thwart the positive effects of marine reserves by eliminating suitable habitat for target and non-target fish assemblages.

Acknowledgements. This project was funded by the Nature Conservancy and the National Marine Fisheries Service Marine Fisheries Initiative Program through grants to J. F. Valentine and K.L.H. Equipment and field support were provided by the University of South Alabama, the Dauphin Island Sea Lab and the generosity of J. F. Valentine, without whom this project would not have been possible. The Dolphin Marina (Little Torch Key, Florida) kindly provided a rental boat following technical difficulties with our research vessel. R. B. Aronson and M. W. Miller provided critical comments on 
this manuscript. B. Furman, M. Vanderklift, D. Blackmon, R. Kroutil and M. Goecker contributed many hours of field and laboratory support. The graduate students at Dauphin Island Sea Lab also provided helpful comments and useful discussion. A. Valdivia graciously assisted with figures. Three anonymous reviewers contributed valuable comments and suggestions.

\section{LITERATURE CITED}

Aronson RB, Precht WF (2000) Herbivory and algal dynamics on the coral reef at Discovery Bay, Jamaica. Limnol Oceanogr 45(1):251-255

Ault JS, Bohnsack JA, Meester GA (1997) Florida Keys National Marine Sanctuary: retrospective (1979-1995) reef fish assessment and a case for protected marine areas. In: Hancock DA, Smith DC, Grant A, Beumer JP (eds) Developing and sustaining world fisheries resources. The state of science and management. CSIRO, Collingwood, Australia, p 415-425

Beaver CR, Jaap WC, Porter JW, Wheaton J and 6 others (2005) Coral reef evaluation and monitoring project (CREMP), 2004 executive summary. Florida Fish and Wildlife Conservation Commission, Fish and Wildlife Research Institute, University of Georgia

Bell JD, Craik GJS, Pollard DA, Russell BC (1985) Estimating length frequency distributions of large reef fish underwater. Coral Reefs 4:41-44

Bellwood DR, Hughes TP, Folke C, Nystrom M (2004) Confronting the coral reef crisis. Nature 429:827-832

Bohnsack JA (1994) How marine fishery reserves can improve reef fisheries. Proc Gulf Caribb Fish Inst 43:217-241

Bohnsack JA, Harper DE (1988) Length-weight relationships of selected marine reef fishes from the southeastern United States and the Caribbean. NOAA Technical Memorandum NMFS-SEFC-215

Bohnsack JA, Harper DE, McClellan DB (1994) Fisheries trends from Monroe County, Florida. Bull Mar Sci 54(3): 982-1018

Bruggemann JH, Kuyper MWM, Breeman AM (1994) Comparative analysis of foraging and habitat use by the sympatric Caribbean parrotfish Scarus vetula and Sparasoma viride (Scaridae). Mar Ecol Prog Ser 112:51-66

Carr MH, Hixon MA (1995) Predation effects on early postsettlement survivorship of coral-reef fishes. Mar Ecol Prog Ser 124:31-42

Connell JH, Hughes TP, Wallace CC (1997) A 30-year study of coral abundance, recruitment, and disturbance at several scales in space and time. Ecol Monogr 67:461-488

Department of Commerce, National Oceanic Atmospheric Administration (1997) Florida Keys National Marine Sanctuary Regulations; Final Rule (15 CFR parts 922, 929, 937). Fed Regist 62(113):32153-32176

Edmunds PJ, Carpenter RC (2001) Recovery of Diadema antillarum reduces macroalgal cover and increases abundance of juvenile corals on a Caribbean reef. Proc Natl Acad Sci 98(9):5067-5071

Florida Keys National Marine Sanctuary, Sanctuary Advisory Council (FKNMS SAC) (2004) Annual Report, July 1, 2003 - June 30, 2004. Florida Department of Environmental Protection and the National Oceanic and Atmospheric Administration (available at: http://floridakeys.noaa.gov/ edu/soundingline/7th_ann_rept_final.pdf)

Goecker M, Heck KL, Valentine JF (2005) Effects of nitrogen concentrations in turtlegrass Thalassia testudinum on con- sumption by the bucktooth parrotfish Sparisoma radians. Mar Ecol Prog Ser 286:239-248

Hay ME (1984) Patterns of fish and urchin grazing on Caribbean coral reefs: are previous results typical? Ecology 65:446-454

Lewis SM (1986) The role of herbivorous fishes in the organization of a Caribbean reef community. Ecol Monogr 56: $183-200$

Luckhurst SE, Luckhurst K (1978) Analysis of the influence of substrate variables on coral reef fish communities. Mar Biol 49:317-323

McClanahan TR (1999) Predation and the control of the sea urchin Echinometra viridis and fleshy algae in the patch reefs of Glovers Reef, Belize. Ecosystems 2:511-523

McClanahan TR (2000) Recovery of a coral reef keystone predator, Balistapus undulatus, in East African marine parks. Biol Conserv 94:191-198

McCormick MI, Holmes TH (2006) Prey experience of predation influences mortality rates at settlement in a coral reef fish, Pomacentrus amboinenesis. J Fish Biol 68:969-974

Mumby, PJ, Dahlgren CP, Harborne AR, Kappel CV and 10 others (2006) Fishing, trophic cascades, and the process of grazing on coral reefs. Science 311:98-101

Pinnegar JK, Polunin NVC, Francour P, Baldalmenti F and 7 others (2000) Trophic cascades in benthic marine ecosystems: lessons for fisheries and protected-area management. Environ Conserv 27(2):179-200

Polunin NVC, Roberts CM (1993) Greater biomass and value of target coral-reef fishes in two small Caribbean marine reserves. Mar Ecol Prog Ser 100:167-176

Roberts CM, Polunin NVC (1991) Are marine reserves effective in management of reef fisheries? Rev Fish Biol Fish 1:65-91

Sammarco PW, Williams AH (1982) Damselfish territoriality: influence on Diadema distribution and implications for coral community structure. Mar Ecol Prog Ser 8:53-59

Santavy DL, Mueller E, Peters EC, MacLaughlin L, Porter JW, Patterson KL, Campbell J (2001) Quantitative assessment of coral diseases in the Florida Keys: strategy and methodology. Hydrobiologia 460:39-52

Shears NT, Babcock RC (2003) Continuing trophic cascade effects after 25 years of no-take marine reserve protection. Mar Ecol Prog Ser 246:1-16

Sobel J, Dalgreen C (2004) Marine reserves: a guide to science, design and use. Island Press, Washington, DC

Steneck RS (1983) Quantifying herbivory on coral reefs: just scratching the surface, and still biting off more than we can chew. In: Reaka ML (ed) The ecology of deep and shallow coral reefs. NOAA Symp Ser Undersea Res, NOAA, Rockville, MD

Stergiou KI (2002) Overfishing, tropicalization of fish stocks, uncertainty and ecosystem management: resharpening Ockham's razor. Fish Res 55:1-9

Suman D, Shivlani M, Milon JW (1999) Perceptions and attitudes regarding marine reserves: a comparison of stakeholder groups in the Florida Keys National Marine Sanctuary. Ocean Coast Manage 42:1019-1040

Valentine JF, Heck KL (2005) Perspective review of the impacts of overfishing on coral reef food web linkages. Coral Reefs 24:209-213

Watson M, Ormond RFG (1994) Effect of an artisanal fishery on the fish and urchin populations of a Kenyan coral reef. Mar Ecol Prog Ser 109:115-129

Williams ID, Polunin VC, Hendrick VJ (2001) Limits to grazing by herbivorous fishes and the impact of low coral cover on macroalgal abundance on a coral reef in Belize. Mar Ecol Prog Ser 222:187-196 